\title{
Correction to: Lucan and Virgil: From Dante to Petrarch (and Boccaccio)
}

\section{Bianca Facchini $^{1}$}

Published online: 4 March 2020

(c) Springer Nature B.V. 2020

\section{Correction to: International Journal of the Classical Tradition https://doi.org/10.1007/s12138-018-0482-x}

Due to an unfortunate turn of events the last paragraph of the article contains erroneous information. "12th-century scholars" should read "20th-century scholars". Please find in this correction document the correct paragraph that should be regarded as the final version by the reader.

To conclude, therefore, Petrarch's and Boccaccio's emphasis on Lucan's biography is an element of discontinuity from Dante, one consonant with their earlyhumanist interest in the lives and personalities of the great authors of antiquity. Unlike 20th-century scholars, however, Petrarch and Boccaccio underscore Lucan's 'anti-Virgilianism' as a biographical trait more than as an element which become part of ideologically characterized readings of the Bellum Civile as an anti-Aeneid.

Publisher's Note Springer Nature remains neutral with regard to jurisdictional claims in published maps and institutional affiliations.

The original article can be found online at https://doi.org/10.1007/s12138-018-0482-x.

Bianca Facchini

b.facchini@ucl.ac.uk

1 Department of Classics, King's College London, North Wing, Strand, London WC2R 2LS, UK 